\title{
SUNDAY STATUTES IN A MODERN COMMUNITY*
}

CRIMIINAL statutes in forty-seven states make it a misdemeanor to conduct all but specifically excepted business and labor on the first day of the week.1. Of ancient origin, these so-called Blue Laws, or Sunday Statutes, aim to make available a weekly time for rest and worship.2 But while society has undergone great changes since their enactment, the statutes remain in their puritanical form. Attempts to enforce these laws in a modern community are, therefore, likely to bring them into conflict with present-day values.

In the recent case of People v. Friedman ${ }^{3}$ two orthodox Jewish retailers

*People v. Friedman, 302 N.Y. 75, 96 N.E. 2d 184 (1950), appcal dismissed, 341 U.S. 907 (1951).

1. Nevada is the only the state without laws regulating conduct on Sunday. Apart from alcoholic beverage restrictions, six states impose only minor limitations on Sunday activity: Arizona prohibits barbering and boxing; California prohibits only bosing; Montana and Oregon prohibit only barbering; Idaho and Wyoming put all Sunday legislation on a local option basis. The remaining forty-one states limit conduct on Sunday in varying degrees of severity. Connecticut, Miaryland, Massachusetts, and New Jersey have the most stringent statutes.

For typical provisions, See Kan. Gen. Stat. AnN. $\$ \$ 21-952$ to $21-956$ (1949).

2. The earliest regulation of Sunday was part of the laws and commandments received by Moses (1571-1451 B.C.) at Mit Sinai, Exodus, $2 x, 9-11$. The first civil regulation occurred during the reign of Emperor Constantine in 321 A.D. The Anglo-Saxon King, Ina, about 691 A.D., and Emperor Charlemagne, early in the ninth century, imposed restrictions on Sunday activity. In 858 A.D. Pope Nicholas announced that worlss of necessity might legally and morally be performed on Sunday. Attending markets on Sunday was forbidden by Henry III of England in 1237. In 1656, the Cromwellian Parliament forbade sale of articles on Sunday. The reign of Charles II witnessed very strict Sunday legislation in England while the continental Sunday was becoming less rigorous.

The first Sunday Law in America was passed by the Colony of Virginia in 1610 . Similar laws were among the first enactments of the other colonies. For a detailed history of the Sunday Law see Johnson and Yost, Separation of Chuscr ard State 219 et seq. (1948).

3. 302 N.Y. 75, 96 N.E. 2d 184 (1950), appeal dismissed, 341 U.S. 907 (1951). Another recent example of enforcement of Sunday laws is Bishop v. Hanna, 218 S.C. 474, 63 S.E. 2d 308 (1951), which dissolved an injunction obtained by operators of stock automobile races to prevent enforcement of the local Sunday Statute and held that the law was valid.

Soon after these decisions the Attorney-General of New York ruled that Sunday automobile races were illegal in that state. N.Y. Times, April 27, 1951, p. 5, col. 2. Within a month two men from Poughkeepsie were arrested for conducting such activity. N.Y. Times, May 25, 1951, p. 23, col. 4. However, this rigorous enforcement scems to have been a shortlived deterrent, for a championship race was scheduled for the Islip (L.I.) Speedway on October 21, 1951. N.Y. Times, Oct. 21, 1951, \$ 5, p. 6, col. 4. Sunday baseball games regularly are halted before completion. See, c.g., N.Y. Times, April 30, 1951, p. 25, col. 4. But see N.Y. Times, May 25, 1951, p. 23, col. 4, reporting the unanimous decision of the Council of the Town of Poughkeepsie not to enforce the New York Sunday Statute against the Ringling Brothers \& Barnum \& Bailey Circus. 
of Kosher meat were convicted under the New York statute for selling uncooked meats on Sunday. ${ }^{4}$ Defendants regularly observed Saturday as their Sabbath and did not trade or labor on that day. ${ }^{5}$ In affirming their conviction, the Court of Appeals stated that the legislature had the power "to regulate the observance of Sunday as a civil and political institution." It held that a statute prohibiting public selling upon Sunday did not offend defendants' religious freedom and was not a law respecting an establishment of religion." Although it had never previously considered a First Amendment challenge to Sunday Statutes, ${ }^{7}$ the Supreme Court of the United States dismissed the appeal for lack of a substantial federal question. ${ }^{8}$

The Friedman decision appears contrary to the Supreme Court's declaration that a "high and impregnable" wall must exist between Church and

4. The conviction was based on N.Y. PenaL LAw $\$ 2147$ (Cum. Supp. 1951) which provides:

"§ 2147. Public traffic on Sunday.

"All manner of public selling or offering for sale of any property upon Sunday is prohibited, except as follows:

"1. Articles of food may be sold, served, supplied and delivered at any time before ten o'clock in the morning;

$* * *$

"5. Delicatessen dealers... may sell, supply, serve and deliver cooked and prepared foods, between the hours of four o'clock in the afternoon and half past seven o'clock in the evening, in addition to the time provided for in stubdivision one hereof. (Emphasis added).

$* * *$

"The provisions of this section, however, shall not be construed to allow or permit the public sale or exposing for sale or delivery of uncooked flesh foods, or meats, fresh or salt, at any hour or time of the day...."

5. Defendants argued that N.Y. Penal LAw $\S 2144$ (Cum. Supp. 1951) was a defense:

"§2144. Persons observing another day as a Sabbath.

"It is a sufficient defense to a prosecution for work or labor on the first day of the week that the defendant uniformly keeps another day of the week as holy time, and does not labor on that day, and that the labor complained of was done in such manner as not to interrupt or disturb other persons in observing the first day of the week, as holy time."

The Court of Appeals held that $\$ 2144$ might not be read into $\$ 2147$ because the exempting language referred only to laboring or working and did not mention selling.

6. People v. Friedman, 302 N.Y. 75, 80, 96 N.E. 2d 184, 186 (1950), appeal disu missed, 341 U.S. 907 (1951).

7. Only two challenges to Sunday Statutes have been considered by the Supreme Court of the United States. Hennington v. Georgia, 163 U.S. 299 (1896), contested a state statute regulating the movement of freight trains within Georgia on Sunday as $\checkmark$ being state regulation of interstate commerce. The statute was upheld as a mere prescription of a rule of civil duty for those within the state on Sunday. In Petit v. Minnesota, 177 U.S. 164 (1900), appellant unsuccessfully attacked as an arbitrary classification a legislative declaration that barbershop operation on Sunday was not necessity or charity.

8. Friedman v. New York, 341 U.S. 907 (1951). 
State. ${ }^{9}$ This doctrine forbids federal or state governments to legislate aid for one religion or all religions, or to force or to influence a person to attend or to remain away from church. ${ }^{10}$ Although in each case the height and penetrability of the dividing barrier may be open to question, ${ }^{11}$ the Fricdnan decision can be reconciled with such reasoning only upon the theory that the Sunday Statute is not religious. ${ }^{12}$ However, Sunday Statutes have a clear religious significance and courts have recognized their tendency to foster and to encourage the Christian religion. ${ }^{13} \mathrm{~A}$ religious purpose is apparent in the statutes' origin 14 and in such titles as "Observance of the Lord's Day"1s or "Offenses Against Morality and Religion."10 Significantly, those activities which are permitted on Sunday generally are limited to periods not conflicting with religious services. ${ }^{17}$ Moreover, several state statutes exempt persons who conscientiously observe a day other than Sunday as their Sabbath. ${ }^{18}$ Finally, by reserving a particular day primarily for religious activity Sunday Statutes tend to influence church attendance.

Apart from their doubtful validity under the First Amendment, Sunday Statutes are unfair in practice. New York's statute, for example, requires

9. Everson v. Board of Education, 330 U.S. 1 (1947). This was emphasized in McCollum v. Board of Education, 333 U.S. 203 (1948). “... the First Amendment rests upon the premise that both religion and government can best work to achicve their loity aims if each is left free from the other within its respective sphere" Id. at 212.

10. Everson v. Board of Education, 330 U.S. 1, 15 (1947); MrcCollum v. Board of Education, 333 U.S. 211 (1948).

11. See Mr. Justice Reed, dissenting, in MicCollum v. Board of Education, 333 U.S. 203, 238 (1948).

12. See Harper \& Etherington, What The Supreme Court Did Not Do In The 1950 Term, 100 U. of PA. L. Rev. 354, 387 (1951).

13. "It is undoubtedly true that... [Sunday Laws have had] ... a tendency to foster and encourage the Christian religion-of all sects and denominations that observe that day-as rest from work and ordinary occupation enables many to engoge in gublic vorship who probably would not otherwise do so. If the Christian religion is... benefited or fostered... as it undoubtedly is, there is all the more reason for the enforcement of laws that help to preserve it." Judefind v. State, 7S Mfd. 510, 515, 28 Atl. 405, 407 (1894), which affirmed defendant's conviction for husking corn on Sunday.

14. See note 2 stipra.

15. Mass. Gen. Laws c. 136 (1948).

16. N.H. REv. LAws c. 448 (1942).

17. E.g., N.Y. Penal Law $\$ 2147$ (Cum. Supp. 1951), supro note 4. Sub-section (1) permits sale of food before 10 a.m. while sub-section (5) permits delicatessens to operate between 4 p.m. and 7:30 p.m. N.Y. Pearal. Law $\$ 2145$ (Cum. Supp. 1951) permits Sunday baseball after 2 p.m. MEE. Rev. STAT. c. 121, $\$ 40$ (1944) permits amateur sports between 1 p.m. and 7 p.m.

18. E.g., N.Y. PeNAL LAw, supra note 5; CoNn. GEN. Star. \$\$609 (1949) excmpts from operation of the Sunday Law any person who observes another day as the Sabbath provided he does not disturb others and has filed written notice of his belief with the prosecuting attorney; R.I. GEN. LAws c. 610 \$21 (1938) permits parsuns observing other days to labor on. Sunday, but they may not open their shops on that day; S.D. CODE $\$ 13.1710$ (1939) permits "servile"labor on Sunday by persons who ubserve other days as the Sabbath. 
that Sunday be observed as the day of "rest" by virtually all in the community. If an individual's religion dictates the observance of another day, then the penalty for holding such religious belief is two days of "rest" in each week. It is an obvious discrimination to impose this economic sanction as a condition of the free exercise of religion. Such discrimination may amount to a denial of the equal protection of the laws. ${ }^{10}$ In addition, enforcement is sometimes discriminatory. It may be argued that the equal protection clause of the Fourteenth Amendment prohibits discriminatory enforcement of a nondiscriminatory law as well as the enactment of a discriminatory law. ${ }^{20}$ In the Friedman case, the Court of Appeals of New York rejected the defendants' claim of discriminatory enforcement for lack of a sufficient offer of proof. ${ }^{21}$ Nevertheless, it seems apparent that prosecutors tend to ignore large offenders while proceeding against small merchants or individual laborers. For example, New York's statute grants no special permission for radio or television broadcasts on the first day of the week. ${ }^{22}$ Yet each Sunday these commercial entertainment media enjoy full operation free from prosecution. It is difficult to understand why the sale of Kosher meat or pigeon feed ${ }^{23}$ on Sunday is a more serious threat to the public health, welfare and morals than "The Shadow" or "The Faye Emerson Show." If financial or personnel limitations require selective prosecution, the rational course is to proceed against that activity having the most far-reaching consequences. In practice the opposite seems to be the rule.

Instead of promoting, Sunday Statutes may actually detract from the public welfare. Unquestionably a periodic day of rest is important to strengthen the mental, physical and moral fiber of the community. However, "rest" may

19. Under Yick Wo v. Hopkins, 118 U.S. 356 (1886), there is no denial of equal protection of the law unless there is an intentional or purposeful discrimination. Such discrimination may appear on the face of action already taken or may be shown by extrinsic evidence. However, a discriminatory purpose will not be presumed. Snowden $v$. Hughes, 321 U.S. 1,8 (1944).

20. See Note, Discriminatory Law Enforcement and Equlal Protection From the Lav, 59 YALE L. J. 354 (1950).

21. "The offer of proof was not an offer to show a pattern of discrimination consciously practiced... [I]t merely indicated some non-enforcement as to certain other businesses many of which were allowed to remain open for the sale of permitted commodities." People v. Friedman, 302 N.Y. 75, 81, 96 N.E. 2d 184, 186-7 (1950), appcal dismissed 341 U.S. 907 (1951). In State v. Trantham, 230 N.C. 641 , 55 S.E. 2d 198 (1949), a similar offer of proof was rejected. "While the evidence tending to show that the... [statutes] are not enforced may serve to indict the police officers... it forms no basis for an attack upon the constitutionality of the ordinance." 230 N.C. $641,645,55$ S.E. 2d 198, 201 (1949).

22. See Appellant's Statement as to Jurisdiction, p. 12.

23. In People v. Shifrin, 198 Misc. 348, 101 N.Y.S. 2d 613 (Nassaut Co. Ct. 1950), the operator of a general feed store was convicted for selling a bag of pigeon feed on Sunday. Christ, J., held that the article sold was "feed" and not within the statutory exception for "food." The Court of Appeals of New York reversed, reasoning that "food" was not limited to human nutriment. People v. Shirin, 301 N.Y. 445, 94 N.E. $2 d 724$ (1950). 
mean recreation as well as idleness and freedom from daily labor. Social scientists assert that recreation is essential to sound emotional adjustment and full character development. ${ }^{24}$ But an individual's personality will control his choice of the type of recreation. ${ }^{25}$ Sunday Statutes err by permitting some activities and prohibiting others which are no less desirable as recreation..$^{0}$ In a heterogeneous community such selective legislation on recreation does not permit the individual to exercise sufficient free choice. What one person enjoys may be tedious for another. Far from promoting a genuine community day of "rest," Sunday Statutes inhibit maximum utilization of leisure time.2T And in most jurisdictions other statutes exist which are better designed to establish regular rest periods ${ }^{28}$ and to keep the peace. ${ }^{20}$

24. See, e.g., Stone, The Fizti of Recrention 26 (1949). The author contends that recreation is a living force in the pattern of life, having creative and therapeutic values. It takes an increased importance in our fractionalized society where living tends to be standardized and regimented. Id. at 2 . Rest alone is not always of avail.

Recreation is said to provide: (1) a complementary experience for daily cccupations which prevents emotional and physical sapping of the individual caused by overconcentrated work; (2) compensation for repressed organic and psychologic impulses; (3) discharge for aggressive drives; (4) fulfillment of the need for a certain amount of regressive behavior by lowering the bars of self-control and decorum; (5) an escape from reality; and (6) satisfaction of social hunger, for recreation seldom is enjoyed in isolation. Slavson, Recreation and the Total Personaltiy 10-16 (1946).

25. Recreation is many things to many people, but whatever the choice of recreation, each individual seeks to satisfy some inner need. Stavsox, op. cit. ropra note 24, at p. $v$.

26. See, e.g., N.Y. PenaI LAW $\$ 2145$ (Cum. Supp. 1951) which permits baseball, basketball, soccer, hockey and football on Sunday after 2 p.m. Such games as polo and lacrosse are no less desirable as recreation, yet they are not permitted by statute. And see Governor Dewey's Annual Message to the New York Legislature, N.Y. Times, Jan. 10, 1952, p. 23, col. 6.

27. Before the Industrial Revolution there was very little leisure time for the large majority of persons. Effective utilization of whatever time was available was not appreciated and was not particularly important. However, the combined effect of technological advance, the small family, and social legislation designed to reduce the number of worl:ing hours has approximately equated the individual's labor and leisure hours. This requires devising means for constructive utilization of the extended leisure time from the viewpoint of both individual growth and community health.

However, "leisure has not automatically signified either the improvement of the individual or the community. Leisure can only make for civilization when there is public action to supplement facilities and leadership of private and commercial facilities." STosie, THE FIEID OF RECREATION 34 (1949).

28. E.g., N.Y. LABor LAw $\$ 161$ (Cum. Supp. 1951) provides a comprehensive system for assuring that workers receive at least one day of rest in every seven. A related regulation covering interstate commerce is the Fair Labor Standards Act, 52 STAr. 1063, 29 U.S.C. $\$ 207$ (1938), as amended, 55 STAт. 756 (1941). This provides, with listed exceptions, that no person may be required to work more than forty hours in any week: unless paid at one and one-half times the normal rate of pay for all hours in excess of forty.

29. There are two types of peace statutes in force relevant to Sunday activity. One prohibits all unnecessary or willful disturbances of the peace and repose of the com- 
The anachronistic nature of Sunday Statutes has caused courts to react in various ways, resulting in a crazy-quilt pattern of judicial enforcement. While no court has gone so far as to consider a statute repealed by implication because of disuse or consistent violation, ${ }^{30}$ some vitiate the statutes by extremely narrow construction. ${ }^{31}$ Other courts have felt obliged to effectuate the general purpose of the laws and to bring their coverage up to date by reading them broadly..$^{32}$ Likewise, courts differ in dealing with statutory exemptions for acts of necessity and charity. ${ }^{33}$ In one jurisdiction the defen-

munity and its several parts. E.g., KAN. GEN. Stat. ANN. \$21-950 (1949). The other prohibits any willful disturbance of religious meetings and worship. E.g., KAN. GeN. Stat. Anv. \$21-949 (1949).

30. Whether a law is unenforced or unenforceable is a legislative question which will not justify judicial intervention. Existing law will be enforced until expressly repealed unless it is totally repugnant to other laws. State v. Malone, 238 Mo. App. 939, 192 S.W. 2d 68 (1946). In State v. Grabinski, 35 Wash. 2d 603, 206 P. $2 d 1022$ (1949), defendant was not permitted to introduce evidence of non-use and widespread violation to cstablish repeal by implication.

31. An example of frustration of legislative intent by strict construction is Jackson v. State, 30 Ala. App. 114, 1 So. $2 \mathrm{~d} 601$ (1941). Defendant was convicted for rolting dice on Sunday. The game was among friends in defendant's backyard and there was no betting. The conviction was reversed on the ground that the statute prohibiting cardplaying, domino-playing and gaming on Sunday had not been violated because rolling dice was not specifically mentioned. Even in the absence of betting, rolling dice reasonably may be included in "gaming."

Some courts apply the rule of ejusdem generis, which means that where general words follow particular words in a statute, the general words will be limited in their meaning to things of the same kind or class as those specified. State v. Prather, 79 Kan. 513,100 Pac. 57 (1909), involved a statute prohibiting "horse-racing, cock-fighting, or playing at cards or game of any kind" on Sunday. Defendant was convicted of playing baseball on Sunday. This was reversed on appeal because baseball was not a "game" within the statute since it was not in the same category with horse-racing, cock-fighting and card-playing. But cf. Worley v. State, 79 Ga. App. 594, 54 S.E. $2 d 439$ (1949), where it was held that an automobile race is a "game" within the meaning of "athletic cvents, games and contests." "Games" and "contests" were regarded as broad generic terms that should be given ordinary significance.

Activity unknown at the time of its enactment has been excluded from the purvicw of a Sunday Statute. State. v. Nashville Baseball Ass'n., 141 Tenn. 456, 211 S.W. 357 (1919), held that professional baseball was unknown to the framers of the statute and therefore not within its terms.

32. There was effectuation of the broad purpose of a statute in Bishop v. Hanna, 218 S.C. 474,63 S.E. $2 d 308$ (1951), where the court construed a statute prohibiting “...public sports or pastimes as bear-baiting, bull-baiting, football playing, horse-racing, interludes or common plays, or other games, exercises, sports or pastimes, such as hunting, shooting, chasing game, or fishing..." to prohibit stock car races. The theory of the court was that the legisiature intended to curtail virtually all Sunday activity and that this preference would be effectuated in spite of the rules of strict construction.

33. Many states exempt acts of necessity and charity from Sunday Statutes. E.g., Kan. Gen. Stat. Ann. §21-952 (1949). 
dant may be required to establish the necessity or charity of his activity, ${ }^{34}$ while in another the prosecution has the burden of showing that the activity was not necessary or charitable. ${ }^{35}$ Moreover, the definitions of necessity and charity are inadequate. Necessity has been described as an act of moral fitness and propriety in view of modern conditions. ${ }^{30}$ Rather than clarifying the concept, this relative terminology has produced a spectrum of results. ${ }^{37}$ Charity has been described as an act evidencing a lack of self-interest and proceeding from a sense of moral duty, kindness and humanity. ${ }^{29}$ However, it has been held that the exception for charity contemplates only acts which are themselves charitable and not detached businesses supporting charitable enterprises. 39

Clearly, Sunday Statutes are undesirable in a modern community. Since the Supreme Court has declined to treat the problem on the constitutional level, the only remaining remedy is repeal. ${ }^{20}$ A program for legislative action should have three phases. First, repeal of all statutes prohibiting or regulat-

34. E.g., Baird v. State, 179 Tenn. 444, 167 S.W. 2d 332 (1943), where defendant was held to have the burden of establishing that operation of a beer parlor and dance hall on Sunday was necessary. This holding seems inconsistent with the traditional theory that in a criminal action the prosecution has the affirmative burden of preof. See 9 WigMrore, EVIDENCE $\$ 2511$ (1) (3d ed. 1948).

35. Williams v. Commonwealth, 179 Va. 741, 20 S.E. 2d 493 (1942), required the state to establish that defendant was not engaged in a work of necessity or charity before there could be a conviction. This view seems more in accord with the principle that an accused is presumed innocent until proven guilty by the state.

36. See Francisco v. Commonwealth, 180 Va. 371, 379, 23 S.E. 2d 234, 238 (1942).

37. The difficulty is applying the concept of necessity to a given act. Sale of gasoline on Sunday has been regarded as a necessity. Williams v. State, $167 \mathrm{Ga} .160,144$ S.E 745 (1928). Contra: Jacobs v. Clark, 112 Vt. 484, 28 A. 2d 369 (1942). But sales of solt drinks, State v. Wortz, 91 W.Va. 622, 114 S.E. 242 (1922), and sales of ice cream products, State v. Corologos, $101 \mathrm{Vt} .300,143 \mathrm{Atl} .284$ (1923), have been held not necessasy. State v. Needham, 134 Kan. 155, 4 P. 2d 464 (1931), held, as a matter of law, that the metropolitan Sunday newspaper was a necessity. The reason was the desirability of learning current events, including news of sports, society, and world affairs. However, the educational value of a natural cavern was not sufficient to justify its operation on Sunday. Perkey Bros. v. Commonwealth, 134 Va. 713, 114 S.E. 764 (1922).

Courts have not interferred with the realtors' most profitable workday, however. A statute prohibiting sale of "any property" was construed not to include real property. People v. Dunford, 207 N.Y. 17, 100 N.E. 433 (1912). Procurement of a home for one's family is a necessity in present civilization and the integrity of the family: is not to be endangered by statutes prohibiting "worldly employment" on Sunday. Chadwick v. Stoles, 162 F. 2d 132 (3d Cir. 1947).

38. Commonwealth v. MicDonald, 32 D. \& C. 257 (Pa. Quar. Sess. 1938).

39. Projectionists, employed by a theatre donating the proceeds of a Sunday performance to a hospital, were held not to be within the statutory exception permitting works of charity because they received regular compensation for their work. Rogers v. State, 60 Ga. App. 722, 4 S.E. $2 d 918$ (1939).

40. Securing repeal is not easy. Although a law may have ceased to reflest public upinion, motivation for outright repeal is tempered by the power of pressure groups. 
ing business, labor or other activity on Sunday. Second, enactment of a statute providing that in every week each person must receive at least one day of rest and that each business must close at least one day, except in emergencies. This is necessary to supplement federal wage and hours laws where state regulation of intra-state commerce is lacking or insufficient.41 Third, enactment of a statute prohibiting any wilful disturbance of a religious mecting whenever held. In addition, conscientious and effective enforcement of existing peace statutes is essential to protect the community right to quiet and repose. Such a system would eliminate the religious overtones of Sunday Statutes while accomplishing their legitimate civil objectives. Effective utilization of leisure time will be permitted and the statute books will be rid of the burden of archaic laws which no longer reflect community mores.

Edgar F. CzarRa, Jr. ${ }^{\dagger}$

In the case of Sunday Statutes there seems to be a moral sense that repeal might desecrate American religious heritage. See note 13 supra.

Most church groups, led by the Lord's Day Alliance, not only oppose repeal of Sunday Laws but agitate for more rigorous laws. Time, Jan. 16, 1950, p. 33, col. 2; Amcrican Mercury, May 1928, p. 91, col. 1.

The Roman Catholic Church is neutral on the subject. Its theory is that if its members attend Mass on Sunday morning they are free to spend the day as they wish. 3 Stokes, Church and State In the United States 174-5 (1950). The American Jewish Congress, on the other hand, has been urging repeal of all Sunday Laws since the Jewish faith is the largest religion observing as the Sabbath a day other than Sunday. News Release, American Jewish Congress, June 29, 1949; News Release, Joint Committee for a Fair Sabbath Law, Dec. 13, 1949. Governor Dewey urged re-examination of the Sunday Statute in his annual message to the legislature. N.Y. Times, Jan. 10, 1952, p. 23, col. 6.

Rigorous enforcement is a device often used to force repeal of Sunday Statutes. In 1932 this was the case in a Baltimore referendum, held after vigorous enforcement, which produced an overwhelming vote in favor of legalized sports on Sunday, Literary Digest, May 21, 1932, p. 19, col. 1.

41. E.g., Mrss. Code ANv. $\$ 6986$ (Cum. Supp. 1950), limits hours of employment to ten per day, but fails to limit the number of hours that maybe worked in any week. But cf. the comprehensive New York statute cited supra, note 28.

†Class of 1952, Yale Law School. 